\title{
DESCRIPTION OF A NEW SPECIES OF LATIRUS.
}

\author{
By James Cosmo Melvill, M.A., D.Sc. \\ Read 8th April, 1910.
}

Latirus Ernesti, n.sp.

$L$. testa mediocri, attenuato-fusiformi, solidiuscula, læté ochraceorufa, anfractibus (fortasse) 6-7, quorum apicales ... (?), cæteris fortiter spiraliter undique tornato-liratis, liris albis, nitidis, inæqualibus, supernis tribus, penultimo sex, ultimo anfractu duodecim liris præditis, interstitiis sub lente delicate alveato-decussatis, apertura ovata, labro paullum effuso, crassiusculo, columella biplicata, canali brevi. Long. 12, lat. $5 \mathrm{~mm}$.

Hab.-Ad Antillarum insulas.

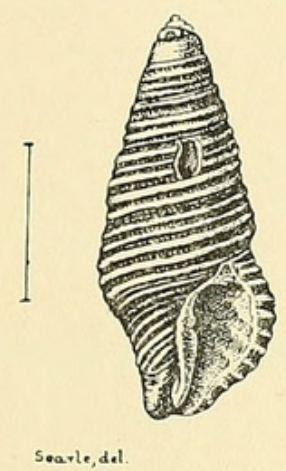

This brightly coloured, ochraceous little Latirus belongs to the typical section of the genus, its allies being $L$. craticulatus, L., or especially turritus, Gmel., of which it seems a miniature resemblance. To lautus, Reeve, there is also some affinity, but it differs altogether both in form and quality of ornamentation of sculpture, lautus being a more obese species, with irregular longitudinal puckering. Mr. Ernest R. Sykes has asked me to describe this interesting addition to the genus, he having received it with the label "W. Indies". The specimen is imperfect; the apical whorls being missing, we should conjecture that if in first-class condition it would be 6-7 whorled; the mouth, however, and the other parts of the shell are good enough for description. I have pleasure in naming it after Mr. Sykes. 


\section{$2 \mathrm{BHL}$ Biodiversity Heritage Library}

Melvill, James Cosmo. 1910. "DESCRIPTION OF A NEW SPECIES OF LATIRUS." Proceedings of the Malacological Society of London 9, 147-147.

View This Item Online: https://www.biodiversitylibrary.org/item/96830

Permalink: https://www.biodiversitylibrary.org/partpdf/203044

\section{Holding Institution}

Field Museum of Natural History Library

\section{Sponsored by}

Smithsonian

\section{Copyright \& Reuse}

Copyright Status: Public domain. The BHL considers that this work is no longer under copyright protection.

This document was created from content at the Biodiversity Heritage Library, the world's largest open access digital library for biodiversity literature and archives. Visit BHL at https://www.biodiversitylibrary.org. 